\title{
Sepsis and septic shock in emergency departments of Mexico: a multicenter point prevalence study
}

\author{
Luis A. Gorordo-Delsol,,2* Graciela Merinos-Sánchez,, ${ }^{2,3}$ Ricardo A. Estrada-Escobar, ${ }^{3}$ \\ Nikolett I. Medveczky-Ordoñez, ${ }^{1}$ Marcos A. Amezcua-Gutiérrez, ${ }^{1}$ Ma. Angélica Morales-Segura ${ }^{4}$ and \\ Silvia E. Uribe-Moya ${ }^{5}$

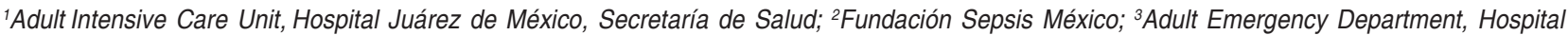 \\ General de México "Dr. Eduardo Liceaga", Secretaría de Salud; " Postgraduate Studies and Research Section, Higher School of Medicine, Instituto \\ Politécnico Nacional; ${ }^{5}$ Emergency Department, Hospital Juárez de México, Secretaría de Salud. Mexico City, Mexico
}

\begin{abstract}
Introduction: Sepsis is one of the main reasons for consultation at emergency departments. Objective: To identify the prevalence of sepsis in emergency departments of Mexico. Method: Cross-sectional study with a 30-day follow-up of patients diagnosed with sepsis or septic shock; demographic variables, management and outcomes were analyzed. Results: In 68 emergency departments analyzed, 2379 patients were attended to, out of whom 307 had sepsis. The prevalence of sepsis was $12.9 \%$, and overall mortality was $16.93 \%$, which in the cases of sepsis was $9.39 \%$, and in those of septic shock, $65.85 \%$; no significant differences were identified in demographic variables or type of hospital. A significantly higher fluid balance was observed within the first three hours in those patients who died, as well as a lack of adherence to international resuscitation recommendations. Conclusions: A high prevalence of sepsis was found in Mexican emergency departments. Mortality of patients with septic shock was similar and even higher than that internationally reported.
\end{abstract}

KEY WORDS: Sepsis. Hospital emergency department. Epidemiology.

\section{Sepsis y choque séptico en los servicios de urgencias de México: estudio multicéntrico de prevalencia puntual}

\section{Resumen}

Introducción: La sepsis es una de las principales causas de consulta en los servicios de urgencias médicas. Objetivo: Identificar la prevalencia de la sepsis en servicios de urgencias médicas de México. Método: Estudio transversal con seguimiento a 30 días de los pacientes con diagnóstico de sepsis o choque séptico; se analizaron las variables demográficas, el manejo y los desenlaces. Resultados: En 68 servicios de urgencias médicas analizados se atendió a 2379 pacientes, de los cuales 307 presentaron sepsis. La prevalencia de la sepsis fue de $12.9 \%$, con mortalidad global de $16.93 \%$, que en los casos de sepsis fue de $9.39 \%$ y en los de choque séptico, de $65.85 \%$; no se identificaron diferencias significativas en las variables demográficas o tipo de hospital. Se observó balance hídrico alto en las primeras tres horas y falta de apego a las recomendaciones internacionales de reanimación superior en los pacientes que fallecieron. Conclusiones: Se encontró alta prevalencia de la sepsis en los servicios de urgencias médicas mexicanos. La mortalidad de los pacientes con choque séptico fue similar e, incluso, mayor a la reportada internacionalmente.

PALABRAS CLAVE: Sepsis. Servicio de emergencias hospitalario. Epidemiología.

Correspondence:

*Luis A. Gorordo-Delsol

E-mail: luis.gorordodelsol@icloud.com
Gac Med Mex. 2020;156:486-492

Contents available at PubMed

www.gacetamedicademexico.com 0016-3813/@ 2020 Academia Nacional de Medicina de México, A.C.. Published by Permanyer. This is an open access article under the CC BY-NC-ND license (http://creativecommons.org/licenses/by-nc-nd/4.0/). 


\section{Introduction}

Sepsis is defined as potentially fatal organ failure caused by a disproportionate response of the body to an infection. ${ }^{1}$ Clinical criteria for sepsis diagnosis include presence of an infection and organ dysfunction or exacerbation of chronic organ failure. ${ }^{1-3}$ Establishing sepsis diagnosis in patients without preexisting organ failure with a Sequential Organ Failure Assessment (SOFA) score $\geq 2$ or with $a \geq 2$-point increase in patients with chronic organ failure is recommended. ${ }^{2-4}$ Septic shock is a sepsis subtype that increases mortality by $40 \%$ and includes circulatory alterations with cellular metabolism abnormalities. ${ }^{5}$

Infections are one of the main causes of attention at emergency departments (EDs), and on numerous occasions they trigger sepsis and septic shock. Paradoxically, most studies focus on the management of patients with sepsis in intensive care units (ICUs), ${ }^{6,7}$ even though initial management at EDs is $\mathrm{key}^{6-8}$ and numerous patients with septic shock will not be admitted to ICUs. ${ }^{1}$ Understanding the relevance of EDs is vital for directing resources and implementing quality improvement measures. ${ }^{9,10}$

Numerous studies, the majority in the United States, Europe and Oceania, ${ }^{11-16}$ focus on care at ICUs: one report included $735 \mathrm{ICUs}$, where 88,371 patients were recorded, $15.08 \%$ with sepsis or septic shock; mortality ranged from $20 \%$ to $59 \% .^{15}$ The EPIC-II trial indicated that $51 \%$ of ICU-admitted patients had ongoing infections. ${ }^{16}$ One study of 18 Mexican ICUs reported that $85 \%$ of admissions were related to sepsis. ${ }^{17}$ Another Mexican study of 135 ICUs indicated that $27.3 \%$ of admissions were due to septic shock, and that $30.4 \%$ of subjects died. ${ }^{18}$ An investigation in EDs recorded that approximately $60 \%$ of patients presented with sepsis and that $10 \%$ were admitted with septic shock. ${ }^{19}$

The purposes of the described research were to identify the prevalence of sepsis at Mexican EDs and to describe the adherence to management recommendations.

\section{Method}

Multicenter, cross-sectional, observational study with a 30-day follow-up to identify the prevalence of sepsis and mortality from this cause in Mexican EDs. The study was approved by the Research Committee with registration number HJM-0515/18-I; informed consent was not required. The Strengthening the Reporting of Observational Studies in Epidemiology (STROBE) initiative recommendations were followed. ${ }^{20}$

Participating centers were recruited by invitation of non-profit organizations Fundación Sepsis México, Mexican Society of Emergency Medicine and Emergency and Disaster Medicine Association of Mexico. Promotion was carried out with announcements at national meetings and social media. Participation was voluntary. Each collaborating center received a copy of the protocol and clearance to access the platform where the work was carried out; in addition, each center was asked to answer a survey on its characteristics.

Patients who were admitted to the participating EDs for a period of 24 hours were included; the platform filtered the patients according to the inclusion criteria: age $\geq 18$ years, confirmed or presumptive diagnosis of sepsis or septic shock according to the definitions established by the Third International Consensus Definitions for Sepsis and Septic Shock (Sepsis-3). ${ }^{2-6,10}$ Patients referred from other institutions were excluded, and patients with therapeutic effort limitation or palliative care indications, or voluntarily discharged or transferred to other institutions were censored. To avoid errors in information capture, the platform was coded with automatic locks. Statistical analysis was conducted by the researchers, and discrepancies were verified with the collaborating centers.

Descriptive analysis of the scale variables was carried out with measures of central tendency and dispersion, and categorical variables were described with frequencies and percentages. The Kolmogorov-Smirnov test was used for normality of the curve, whereby non-parametric results were obtained and, subsequently, Mann-Whitney's U-test was applied. Between-group associations and variables were determined using the chi-square test, whereas the comparison between groups was carried out using Fisher's exact test. Risk factors were measured with odds ratios (ORs) and $95 \%$ confidence intervals $(\mathrm{Cl})$; association between more than two means was established with Spearman correlation coefficient. The results were significant when the $p$-value was $<0.05$. The SPSS statistical program, version 21, was used. Missing data were addressed by elimination of cases or mean value imputation.

\section{Results}

Two hundred and eleven collaborating centers were registered, out of which 13 were not eligible for being 
specialized EDs; of 198 eligible EDs, 101 (47.86\%) answered the initial survey and only $68(32.22 \%)$ included patients in the study (Fig. 1).

On the day of the study, 2,379 patients were admitted to participant EDs; 307 patients (12.9\%) were diagnosed with sepsis, and 41 of them (13.35\%) arrived with septic shock. Five private and 63 public hospitals participated, with no differences in 30-day all-cause mortality risk $(\mathrm{OR}=1.093,95 \% \mathrm{Cl}=0.229$ $5.214, p=0.911$. Mean age was 53.6 years, with no significant differences between survivors and non-survivors. One hundred and seventy-two women $(56.02 \%)$ were recorded; gender was not associated with a higher 30 -day mortality risk $(\mathrm{OR}=1.314,95 \%$ $\mathrm{Cl}=0.714-2.421, \mathrm{p}=0.380$ ). Average body mass in$\operatorname{dex}\left(\mathrm{kg} / \mathrm{m}^{2}\right)$ was 26.7 .

A prevalence of sepsis and septic shock of $12.9 \%$ was identified in the study population (95\% $\mathrm{Cl}=11.62-14.11 \%)$; of the 307 included patients, in $266(86.64 \%)$ were the sepsis criteria and in 41 $(13.35 \%)$ the septic shock criteria met at admission. Overall mortality was $16.93 \%, 9.39 \%$ in patients with sepsis and $65.85 \%$ in those with septic shock, which translated into a significant association between septic shock and 30-day mortality, with an OR $=18.5914$ $(95 \% \mathrm{Cl}=8.6456-39.9806, \mathrm{p}=0.0001)$.

The most common infection was urinary tract infection, followed by community-acquired pneumonia. Pneumonia was the only cause of sepsis that was associated with a significant 30-day mortality increase $(\mathrm{OR}=1.9429$, $95 \% \mathrm{Cl}=1.0085-3.7428, p=0.0471$; table 1).

Of the 307 cases, lactate quantification was carried out in 64 patients $(20.8 \%)$. One hundred and sixty-eight cultures were obtained ( 70 from blood, 53 from urine, 19 from sputum, five from sputum trap and 21 from other secretions) from 120 patients $(39.08 \%)$, out of which $19.64 \%$ were positive. Only 287 patients received antibiotics during their stay at EDs; in $29.96 \%$, they were started during the first hour (Table 2).

Among the patients in whom a fluid balance $\geq 30 \mathrm{~mL} / \mathrm{kg}$ was observed within the first three hours, total cumulative in survivors and non-survivors was similar (39.95 and $39.94 \mathrm{~mL} / \mathrm{kg}, \mathrm{p}=0.7263$ ); among the patients in whom fluid balance remained below $30 \mathrm{~mL} / \mathrm{kg}$ within the first three hours, the mean between survivors and non-survivors was not different (7.74 and $9.19 \mathrm{~mL} / \mathrm{kg}, \mathrm{p}=0.7565$ ). Among the patients in whom the $\geq 30 \mathrm{~mL} / \mathrm{kg}$ fluid balance goal was not achieved, a reduction in 30-day mortality was observed $(O R=0.2820,95 \% \mathrm{Cl}=0.1341-0.593$, $p=0.001$ ), in comparison with those in whom it was

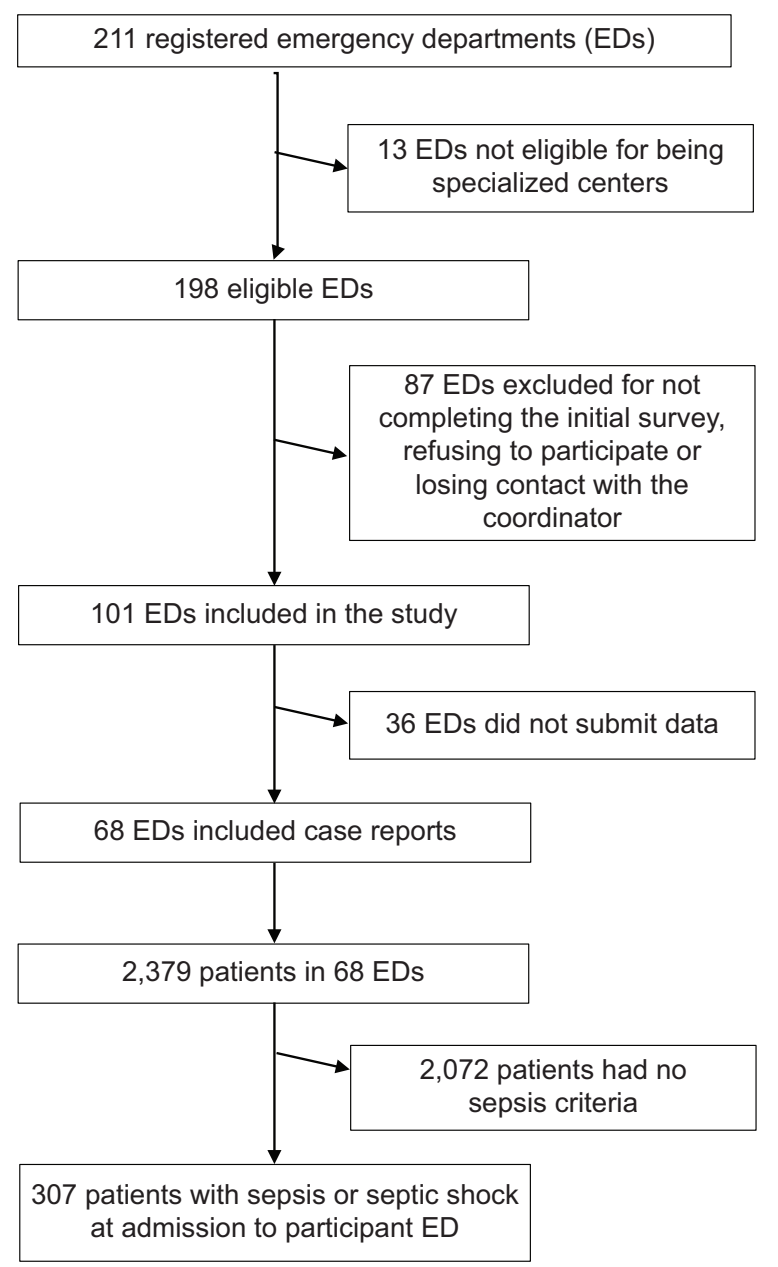

Figure 1. Participating centers and patients inclusion flowchart.

achieved; average in survivors was significantly lower than in non-survivors (10.68 vs. $17.4 \mathrm{~mL} / \mathrm{kg}, \mathrm{p}=0.0271$ ). Cumulative fluid balance within the first six hours was 42.6 vs. $62.2 \mathrm{~mL} / \mathrm{kg}(\mathrm{p}=0.0587)$, and at 24 hours, 35 vs. $47 \mathrm{~mL} / \mathrm{kg}(p=0.0969)$.

Four of the nine patients in whom recommended resuscitation measures were complied with within the first hour ${ }^{21}$ and 48 of 298 patients in whom they were not complied died, with a positive association between not meeting the goals and lower mortality $(\mathrm{OR}=0.240$, $95 \% \mathrm{Cl}=0.062-0.926, p=0.038)$. As for implementation of the recommended measures within three and six hours, ${ }^{22}$ an association between non-compliance and lower 30-day mortality risk was observed $(\mathrm{OR}=0.143,95 \% \mathrm{Cl}=0.031-0.659, \mathrm{p}=0.013)$.

\section{Discussion}

Demographic variables such as hospital type, age, gender and body mass index did not influence 
Table 1. Demographic data, source of infection and severity scales in patients with sepsis admitted to emergency departments

\begin{tabular}{|c|c|c|c|c|c|c|}
\hline & \multicolumn{2}{|c|}{ All patients } & \multicolumn{2}{|c|}{ Survivors } & Non-survivors & $p$ \\
\hline & \multicolumn{2}{|c|}{ Mean } & \multicolumn{2}{|c|}{ Mean } & Mean & \\
\hline Age, years & \multicolumn{2}{|c|}{53.6} & \multicolumn{2}{|c|}{52.38} & 59.57 & 0.023 \\
\hline $\begin{array}{l}\text { Severity scales at emergency department admission } \\
\text { APACHE II } \\
\text { SAPS II } \\
\text { SOFA } \\
\text { qSOFA } \\
\text { MPM-II }\end{array}$ & \multicolumn{2}{|c|}{$\begin{array}{c}10.65 \\
32.47 \\
5.22 \\
0.99 \\
15.21\end{array}$} & \multicolumn{2}{|c|}{$\begin{array}{c}9.43 \\
30.62 \\
4.82 \\
0.82 \\
12.77\end{array}$} & $\begin{array}{c}16.95 \\
42.08 \\
7.32 \\
1.78 \\
28.26\end{array}$ & $\begin{array}{l}<0.0001 \\
<0.0001 \\
<0.0001 \\
<0.0001 \\
<0.0001\end{array}$ \\
\hline & \multicolumn{2}{|c|}{$\mathrm{n}$} & \multicolumn{2}{|c|}{$\mathrm{n}$} & $\mathrm{n}$ & \\
\hline $\begin{array}{l}\text { Gender } \\
\text { Females } \\
\text { Males }\end{array}$ & \multicolumn{2}{|c|}{$\begin{array}{l}172 \\
135\end{array}$} & \multicolumn{2}{|c|}{$\begin{array}{l}140 \\
115\end{array}$} & $\begin{array}{l}32 \\
20\end{array}$ & 0.380 \\
\hline BMI $\left(\mathrm{kg} / \mathrm{m}^{2}\right)$ & \multicolumn{2}{|c|}{26.7} & \multicolumn{2}{|c|}{26.8} & 26.5 & 0.6718 \\
\hline $\begin{array}{l}\text { Type of institution } \\
\text { Public } \\
\text { Private }\end{array}$ & \multicolumn{2}{|c|}{$\begin{array}{c}296 \\
11\end{array}$} & \multicolumn{2}{|c|}{$\begin{array}{c}246 \\
9\end{array}$} & $\begin{array}{c}50 \\
2\end{array}$ & 0.911 \\
\hline $\begin{array}{l}\text { Sepsis severity } \\
\text { Sepsis } \\
\text { Septic shock }\end{array}$ & \multicolumn{2}{|c|}{$\begin{array}{c}266 \\
41\end{array}$} & \multicolumn{2}{|c|}{$\begin{array}{c}241 \\
14\end{array}$} & $\begin{array}{l}25 \\
27\end{array}$ & $\leq 0.0001$ \\
\hline & $n$ & $\%$ & $n$ & $\%$ & $n$ & $\%$ \\
\hline $\begin{array}{l}\text { Infection site } \\
\text { Pneumonia } \\
\text { Thoracic surgery } \\
\text { Non-intra-abdominal surgery } \\
\text { Intra-abdominal surgery } \\
\text { Urinary tract } \\
\text { Skin and soft tissues } \\
\text { Other }\end{array}$ & $\begin{array}{c}68 / 307 \\
2 / 307 \\
43 / 307 \\
25 / 307 \\
97 / 307 \\
51 / 307 \\
21 / 307\end{array}$ & $\begin{array}{c}22.1 \\
0.6 \\
14 \\
8.1 \\
31.5 \\
16.6 \\
6.8\end{array}$ & $\begin{array}{l}51 / 68 \\
2 / 2 \\
37 / 43 \\
20 / 25 \\
87 / 97 \\
46 / 51 \\
12 / 21\end{array}$ & $\begin{array}{c}75 \\
100 \\
86 \\
80 \\
89.6 \\
90.1 \\
57.14\end{array}$ & $\begin{array}{c}17 / 68 \\
0 / 2 \\
6 / 43 \\
5 / 25 \\
10 / 97 \\
5 / 51 \\
9 / 21\end{array}$ & $\begin{array}{c}25 \\
0 \\
14 \\
20 \\
10.3 \\
9.8 \\
42.8\end{array}$ \\
\hline
\end{tabular}

mortality, which in patients who developed septic shock was higher than in those who only presented with sepsis., ${ }^{1,2,5}$ Among the infections, those of the urinary tract and pneumonia stand out, with the latter increasing the mortality risk; a high number of patients with urinary infection reported negative cultures. ${ }^{8,9,19}$ Severity assessment scales (APACHE II, SAPS II, SOFA, qSOFA and MPMO-II) mean scores were significantly higher in patients who died. ${ }^{2}$

We observed that lactate was significantly higher in non-survivors. Slightly less than $40 \%$ of patients underwent cultures for microbiological isolation; however, the yield did not reach $20 \%$. It was alarming that slightly less than $30 \%$ received antimicrobial treatment within the first hour. A reduced number of patients received the amount of fluids recommended by the guidelines; ${ }^{22}$ however, receiving less fluids was associated with lower mortality, probably owing to less fluid overload.

Of note, in few cases was full compliance with resuscitation goals achieved. ${ }^{21,22}$ This result should be interpreted with caution, since the low number of patients in whom these recommendations were complied with can bias the analysis and denote results that may not be true in daily practice; furthermore, those recommendations were designed for high-income countries and with a focus on intensive care units, not on EDs.

\section{Strengths and limitations}

This study has some limitations:

1. Participation in the study was voluntary, and we are not sure that the sample is sufficient or random, or that it represents Mexico's EDs. 
Table 2. Adherence to resuscitation goals* in patients with sepsis admitted to emergency departments

\begin{tabular}{|c|c|c|c|c|c|c|c|}
\hline & \multicolumn{2}{|c|}{ All patients } & \multicolumn{2}{|c|}{ Survivors } & \multicolumn{2}{|c|}{ Non-survivors } & \multirow[t]{2}{*}{ p } \\
\hline & $\mathrm{n}$ & $\%$ & $\mathrm{n}$ & $\%$ & $\mathrm{n}$ & $\%$ & \\
\hline $\begin{array}{l}\text { Lactate sampling } \\
\text { Yes } \\
\text { No }\end{array}$ & $\begin{array}{c}64 / 307 \\
243 / 307\end{array}$ & $\begin{array}{l}20.8 \\
79.1\end{array}$ & $\begin{array}{c}43 / 64 \\
212 / 243\end{array}$ & $\begin{array}{l}67.1 \\
87.2\end{array}$ & $\begin{array}{c}21 / 64 \\
31 / 243\end{array}$ & $\begin{array}{l}32.8 \\
12.7\end{array}$ & 0.0002 \\
\hline $\begin{array}{l}\text { Procurement of cultures } \\
\text { Yes } \\
\text { No }\end{array}$ & $\begin{array}{c}72 / 307 \\
235 / 307\end{array}$ & $\begin{array}{l}23.4 \\
76.5\end{array}$ & $\begin{array}{c}53 / 72 \\
202 / 235\end{array}$ & $\begin{array}{l}73.6 \\
85.9\end{array}$ & $\begin{array}{c}19 / 72 \\
33 / 235\end{array}$ & $\begin{array}{c}26.3 \\
14\end{array}$ & 0.0162 \\
\hline $\begin{array}{l}\text { Antibiotic within first hour } \\
\text { Yes } \\
\text { No }\end{array}$ & $\begin{array}{c}86 / 287 \\
201 / 287\end{array}$ & $\begin{array}{l}29.96 \\
70.03\end{array}$ & $\begin{array}{c}71 / 86 \\
168 / 201\end{array}$ & $\begin{array}{l}82.5 \\
83.5\end{array}$ & $\begin{array}{c}15 / 86 \\
33 / 201\end{array}$ & $\begin{array}{l}17.4 \\
16.4\end{array}$ & 0.055 \\
\hline \multicolumn{8}{|c|}{ Fluid goal: $30 \mathrm{~mL} / \mathrm{kg}$ within first three hours } \\
\hline & $n$ & Mean & $\mathrm{n}$ & Mean & $\mathrm{n}$ & Mean & \\
\hline Yes & $38 / 307$ & 39.28 & $24 / 38$ & 38.95 & $14 / 38$ & 39.94 & 0.7263 \\
\hline No & $269 / 307$ & 7.95 & $231 / 269$ & 7.74 & $38 / 269$ & 9.19 & 0.7565 \\
\hline \multicolumn{8}{|c|}{ Adherence to goals within first hour } \\
\hline & \multicolumn{2}{|c|}{$\mathrm{n}$} & \multicolumn{2}{|c|}{$\mathrm{n}$} & \multicolumn{2}{|c|}{ n } & \\
\hline Yes & \multicolumn{2}{|c|}{ 9/307 } & \multicolumn{2}{|c|}{$5 / 9$} & \multicolumn{2}{|c|}{$4 / 9$} & م? \\
\hline No & \multicolumn{2}{|c|}{$298 / 307$} & \multicolumn{2}{|c|}{250} & \multicolumn{2}{|c|}{$48 / 298$} & \\
\hline \multirow[t]{2}{*}{$\begin{array}{l}\text { Adherence to goals within } \\
\text { Yes } \\
\text { No }\end{array}$} & \multicolumn{2}{|c|}{$\begin{array}{c}7 / 307 \\
300 / 307\end{array}$} & \multicolumn{2}{|c|}{$\begin{array}{c}3 / 7 \\
252 / 300\end{array}$} & \multicolumn{2}{|c|}{$\begin{array}{c}4 / 7 \\
48 / 300\end{array}$} & 0.013 \\
\hline & \multicolumn{2}{|c|}{ Mean } & \multicolumn{2}{|c|}{ Mean } & \multicolumn{2}{|c|}{ Mean } & \\
\hline Arterial lactate (mmol/L) & \multicolumn{2}{|c|}{3.57} & \multicolumn{2}{|c|}{2.737} & \multicolumn{2}{|c|}{5.28} & 0.003 \\
\hline $\begin{array}{l}\text { Cumulative fluid balance } \\
\text { First } 3 \text { hours } \\
\text { First } 6 \text { hours } \\
\text { First } 24 \text { hours }\end{array}$ & \multicolumn{2}{|c|}{$\begin{array}{c}11.83 \\
46.09 \\
37\end{array}$} & \multicolumn{2}{|c|}{$\begin{array}{c}10.68 \\
42.60 \\
35\end{array}$} & \multicolumn{2}{|c|}{$\begin{array}{c}17.44 \\
62.20 \\
47\end{array}$} & $\begin{array}{l}0.0271 \\
0.0587 \\
0.0969\end{array}$ \\
\hline
\end{tabular}

2. Participation of private hospitals was very low and we cannot determine the effect of this on the results.

3. Urinalysis was observed to be used to diagnose urinary tract infections, which can lead to overdiagnosis.

4. Some participant EDs lack physicians specialized in emergency medicine, others are university hospitals, some have a department of infectious diseases, which may have an influence on optimal antimicrobial treatment, and others are tertiary hospitals with excellent resources. We do not know the impact of all these variables on the quality of care, compliance with resuscitation goals and management at ED discharge.
5. We do not know about ED-assigned personnel training, updating, use of care protocols and educational qualifications.

Despite the above, this was a large prospective epidemiological study, which provides valuable information about sepsis in Mexico's EDs that can serve as a basis for future research focused on pathogens, infections, risk factors, antimicrobials, fluid management and quality of care, among other issues.

\section{Interpretation}

There are no similar studies related to emergency departments of Latin America. The observed prevalence of sepsis of $12.9 \%$ was higher than that 
indicated in other studies carried out at emergency departments of the United States $(0.64 \%, 95 \%$ $\mathrm{Cl}=0.57-0.73 \%)^{9}$ and the United Kingdom (4.3\%, 95 $\% \mathrm{Cl}=3.3-5.2 \%)^{7}$ and represented nearly the double of that observed in Turkish ICUs $(6.9 \%)^{23}$ or half of that recorded in Brazilian ICUs (30.2\%). ${ }^{24}$ As for demographic variables and infection site, we did not find important differences, although a high frequency of urinary tract infections was recorded in comparison with other series. ${ }^{7,9,10,23-25}$

We observed an alarming lack of resources with regard to lactate measurement, laboratory tests, cultures, access to antibiotics in an acceptable time and resuscitation goals achievement. We found that patients who did not receive fluid resuscitation according to international recommendations ${ }^{21,22}$ had lower mortality. Although timely fluid resuscitation has been shown to be associated with lower mortality, ${ }^{26}$ fluid overload harmful effects are also an important risk factor for higher mortality. ${ }^{27-30}$

We believe that there are various unmeasured factors in this study that affect the care of sepsis patients in Mexico: care provided at offices adjacent to pharmacies can reduce the possibiities of prevention and increase inappropriate prescription of antimicrobials; ${ }^{31}$ EDs overcrowding due to the lack of triage procedures, late referral and insufficient personnel or resources; ${ }^{32,33}$ restricted access to microbiology laboratory services at certain hours; low levels of reference to the intensive care unit (less than $8 \%$ of patients in this cohort); and lack of knowledge about national guidelines for the management of sepsis ${ }^{34-36}$ and other related documents ${ }^{37-40}$ or preference for using international guidelines.

In conclusion, we found that the prevalence and mortality of patients with sepsis at Mexican EDs were high. Limited access to resources can be a risk factor associated with mortality. Training and surveillance programs are needed in order to improve the quality of care, which should seek to reduce the burden ${ }^{41}$ sepsis represents for the Mexican health system.

\section{Author contributions}

Luis A. Gorordo-Delsol had full access to all data and is responsible for their integrity and accuracy of their analysis; in addition, together with Graciela Merinos-Sánchez and Ma. Angélica Morales-Segura, he participated in data statistical analysis. All authors directly and substantially participated in the design and interpretation of results and substantially contributed to the writing, review and approval of the final manuscript.

\section{Conflicts of interest}

There are no conflicts of interest to report.

\section{Funding}

No subsidy was received for this study.

\section{Ethical disclosures}

Protection of human and animal subjects. The authors declare that the procedures that were followed adhered to the ethical standards of the responsible human experimentation committee and to the World Medical Association and the Declaration of Helsinki guidelines.

Confidentiality of data. The authors declare that they have followed the protocols of their work center on the publication of patient data.

Right to privacy and informed consent. Given the nature of the investigation, obtaining informed consent was not necessary.

\section{References}

1. Singer M, Deutschman CS, Seymour CW, Shankar-Hari M, Annane D, Bauer M, et al. The Third International Consensus Definitions for Sepsis and Septic Shock (Sepsis-3). JAMA. 2016;315:801-810.

2. Seymour CW, Cinvent XL, Iwashyma TJ, Brunkhorst FM, Rea TD, Scherag A, et al. Assessment of clinical criteria for sepsis: for the Third International Consensus Definitions for Sepsis and Septic Shock (Sepsis-3). JAMA. 2016;315:762-774.

3. Donnelly JP, Safford MM, Shapiro NI, Baddley JW, Wang HE. Application of the Third International Consensus Definitions for Sepsis (Sepsis-3) classification: a retrospective population-based cohort study. Lancet Inf Dis. 2017;17:661-670.

4. Machado FR, Nsutebu E, AbDulaziz S, Daniels R, Finfer S, Kissoon N et al. Sepsis 3 from the perspective of clinicians and quality improvement initiatives. J Crit Care. 2017;40:315-317.

5. Shankar-Hari M, Phillips GS, Levy ML, Seymour CW, Liu VX, Deutschman CS, et al. Developing a new definition and assessing new clinical criteria for septic shock for the Third International Consensus Definitions for Sepsis and Septic Shock (Sepsis-3). JAMA. 2016:315:775-787.

6. Ibrahim I. Sepsis: the need for epidemiological studies in the emergency department. J Emer Med. 2014;46:e93-e94.

7. Cowan SL, Holland JAA, Kane AD, Frost I, Boyle AA. The burden of sepsis in the emergency department: an observational snapshot. Eur $\mathrm{J}$ Emerg Med. 2015;22:363-365.

8. Yu CW, Chang SS, Lai CC, Wu JY, Yen DW, Lee MG, et al. Epidemiology of emergency department sepsis: a national cohort study between 2001 and 2012. Shock. 2019;51:619-624.

9. Wang HE, Joes AR, Donnelly JP. Revised national estimates of emergency department visits for sepsis in the United States. Crit Care Med. 2017;45:1443-1449.

10. Wang HE, Shapiro NI, Angus DC, Yealy DM. National estimates of severe sepsis in United States emergency departments. Crit Care Med. 2007:35:1928-1936.

11. Angus DC, Linde-Zwirble WT, Lidicker J, Clermont G, Cardillo J, Pinsky MR. Epidemiology of severe sepsis in the United States: analysis of incidence, outcome, and associated cost of care. Crit Care Med. 2001;29:1303-1310.

12. Lide-Zwirble WT, Angus DC. Severe sepsis epidemiology: sampling, selection, and society. Crit Care. 2004;8:222-226. 
13. van Dillen J, Zwart J, Schutte J, van Roosmalen J. Maternal sepsis: epidemiology, etiology and outcome. Curr Opin Infect Dis. 2010;23:249-254

14. Watson RS, Carcilo JA. Scope and epidemiology of pediatric sepsis. Pediatr Crit Care Med. 2005;6:S3-S5.

15. Rhodes A, Phillips G, Beale R, Cecconi M, Chiche JD, de Backer D, et al. The Surviving Sepsis Campaign Bundles and outcome: results from the International Multicentre Prevalence Study on Sepsis (the IMPreSS study). Intensive Care Med. 2015;41:1620-1628

16. Vincent JL, Rello J, Marchall J, Silva E, Anzueto A, Martín CD, et al. International study of the prevalence and outcomes of infection in intensive care units. JAMA. 2009;302:2323-2329.

17. Cabrera A, Laguna G, López G, Villagómez A, Méndez R, Guzmán R. Mecanismos patogénicos en sepsis y choque séptico. Med Int Mex. 2008;24:38-42.

18. Carrillo R, Carrillo JR, Carrillo LD. Estudio epidemiológico de la sepsis en unidades de terapia intensiva mexicanas. Cir Cir. 2009;77:301-308.

19. Gorordo-Delsol LA, Mérida-García JA, López-Gómez A. Sepsis: más allá de la enfermedad. Arch Med Urg Mex. 2014;6:12-16.

20. Von Elm E, Altman DG, Egger M, Pocock SJ, Gøtzsche PC, Vanderbroucke JP, et al. The Strengthening the Reporting of Observationa Studies in Epidemiology (STROBE) statement: guidelines for reporting observational studies. J Clin Epidemiol. 2008;61:344-349.

21. Levy MM, Evans LE, Rhodes A. The Surviving Sepsis Campaign Bundle: 2018 update. Intensive Care Med. 2018;46:997-1000.

22. Rhodes A, Evans LE, Alhazzani W, Levy M, Massimo A, Ferrer R, et al Surviving Sepsis Campaign: International Guidelines for Management of Sepsis and Septic Shock: 2016. Intensive Care Med. 2017;43:304-377.

23. Baykara N, Akalın H, Arslantaş MK, Hancı V, Cağlayan C, Kahveci F, et al. Epidemiology of sepsis in intensive care units in Turkey: a multicenter, point-prevalence study. Crit Care. 2018;22:93.

24. Machado FR, Cavalcanti AB, Bozza FA, Ferreira EM, Angotti Carras FS Sousa JL, et al. The epidemiology of sepsis in Brazilian intensive care units (the Sepsis PREvalence Assessment Database, SPREAD): an observational study. Lancet Infect Dis. 2017;17:1180-1189.

25. Rezende E, Silva JM, Isola AM, Campos EV, Amendola CP, Almeida SL. Epidemiology of severe sepsis in the emergency department and difficulties in the initial assistance. Clinics (Sao Paulo). 2008;63:457-464.

26. Leisman D, Wie B, Doerfler M, Bianculliu A, Ward MF, Akerman M, et al. Association of fluid resuscitation initiation within 30 minutes of severe sepsis and septic shock recognition with reduced mortality and length of stay. Ann Emerg Med. 2016;68:298-311.
27. Boyd JH, Forbes J, Nakada TA, Walley KR, Russel JA. Fluid resuscitation in septic shock: a positive fluid balance and elevated central venous pressure are associated with increased mortality. Crit Care Med. 2011;39:259-265.

28. Mithell KH, Carlbom D, Cadwell E, Leary PJ, Himmelfarb J, Houg CL. Volume overload: prevalence, risk factors, and functional outcome in survivors of septic shock. Ann Am Thorac Soc. 2015;12:1837-1844.

29. De Oliveira FS, Freitas FG, Farreira EM, de Castro I, Bafi AT, de Azevedo LC, et al. Positive fluid balance as a prognostic factor for mortality and acute kidney injury in severe sepsis and septic shock. J Crit Care. 2015;30:97-101.

30. Sirvent JM, Ferri C, Baró A, Murcia C, Lorencio C. Fluid balance in sepsis and septic shock as a determining factor of mortality. Am J Emerg Med. 2015;33:186-189.

31. Dreser A, Wirtz VJ, Corbett KK, Echániz G. Uso de antibióticos en México: revisión de problemas y políticas. Salud Publica Mex 2008;50:S480-S487.

32. Castañón-González JA, Barrientos-Fortes T, Polanco-González C. Reflexiones sobre el proceso de atención en los servicios de urgencias. Rev Med Inst Mex Seg Soc. 2016;54:376-379.

33. Gorordo-Delsol LA, Merinos-Sánchez G. Urgencias: ¿dónde están los especialistas? Rev Med Inst Mex Seg Soc. 2017;55:7-8.

34. Diagnóstico y tratamiento de sepsis y choque séptico en pacientes de 1 mes a 18 años de edad. Mexico: Secretaría de Salud; 2008.

35. Diagnóstico y tratamiento de sepsis grave y choque séptico en el adulto. Mexico: Secretaría de Salud; 2009.

36. Secretaría de Salud. Guía de Práctica Clínica: prevención, diagnóstico y tratamiento de la sepsis materna. México: Secretaría de Salud; 2018.

37. Norma Oficial Mexicana NOM-045-SSA2-2005, para la vigilancia epidemiológica, prevención y control de las infecciones nosocomiales. Mexico: Diario Oficial de la Federación; 2009.

38. Acuerdo por el que se declara la obligatoriedad de la Estrategia Nacional de Acción contra la Resistencia a los Antimicrobianos. Mexico: Diario Oficial de la Federación; 2018.

39. Reinhart K, Daniels R, Kisoon N, Machado FR, Schachter RD, Finfer S. Recognizing sepsis as a global health priority - A WHO resolution. N Engl J Med. 2017;377:414-417.

40. Azevedo LCP, Cavalcanti AB, Lisboa T, Dal Pizzol F, Machado FR. Sepsis in an important healthcare burden in Latin America: a call to action! Rev Bras Ter Intensiva. 2018;30;402-404.

41. Gorordo-Delsol LA. Sepsis: the hidden enemy between the lines. Rev Med Inst Mex Seguro Soc. 2017;55:423. 